\title{
Towards Plurilingualism: The Future of Foreign Languages in Saudi Arabia
}

\author{
Haifa Alnofaie \\ Department of Foreign Languages, Taif University, Taif, Saudi Arabia \\ Email: haifa.alnofaie@gmail.com
}

How to cite this paper: Alnofaie, $\mathrm{H}$. (2017). Towards Plurilingualism: The Future of Foreign Languages in Saudi Arabia. Open Journal of Modern Linguistics, 7, 238-261.

https://doi.org/10.4236/ojml.2017.75018

Received: September 24, 2017

Accepted: October 20, 2017

Published: October 23, 2017

Copyright $\odot 2017$ by author and Scientific Research Publishing Inc. This work is licensed under the Creative Commons Attribution International License (CC BY 4.0).

http://creativecommons.org/licenses/by/4.0/

(c) (i) Open Access

\begin{abstract}
This paper discusses the phenomenon of plurilingualism that has emerged among Saudi youth. Although research on this topic is scarce, a few existing studies have revealed that various foreign languages which are not taught in Saudi schools or in Higher Education (HE) institutions, and are not spoken by Saudis, have gained high popularity among Saudi young people and children (Payne \& Almansour, 2014; Alnofaie, 2016). This paper identifies popular foreign languages that are learnt by undergraduate Saudi females, explains their attitudes and motivation towards learning these languages and finally draws implications for a new policy of teaching foreign languages in Saudi's HE sector. An attitudinal and motivational survey designed by Dörnyei \& Csizér (2002) was adapted for data collection. The overall finding was that globalisation has had an obvious impact on Saudi youth in terms of building positive attitudes towards and motivation for learning foreign languages. This study adds to the small body of available literature on learning foreign languages that are not widely spoken in the country. It calls for rethinking foreign language teaching in Saudi HE institutions and highlights the need for a policy that encourages the teaching of diverse foreign languages. This study might inform language educators in other Middle Eastern and Asian countries whose youth might have developed an interest in learning various foreign languages.
\end{abstract}

\section{Keywords}

Plurilingualism, Youth, Attitudes, Motivation, Globalisation, Language Teaching Policy

\section{Introduction}

\subsection{Globalisation and Plurilingualism}

Globalisation is an empirical phenomenon that refers to the interconnectedness 
of world politics, economy and culture. It was first referred to by Dewey (1993: p. 110) who explains the interrelatedness of the world on both commercial and economic levels. One cannot deny the influence of globalisation on the world as a result of financial markets, communicative technologies and geopolitical moves (Giddens, 2001). Kubota (2002: p. 13) views globalisation as another term for Westernisation, more specifically Americanization. This view by Kubota emphasises the culture that is associated with the economic power of America and the West. The effect of globalisation has reached education and its association with Western cultures has raised concerns about the compatibility of Western educational policy with non-Western contexts (Parjanadze, 2009). The association of globalisation with Americanisation and the power of the British Empire (see Crystal, 2003: pp. 5-9) has led to the spread of English as a global language. The dominance of English, in turn, has enriched the field of teaching and learning English as a foreign language (EFL) with many theories and applications.

Despite some concerns that the dominance of one Western culture might negate the influence of other non-Western cultures (see Papastephanou, 2005), globalisation has contributed to the spread of non-world languages and cultures. Living in a global world where people feel connected at all levels: political, cultural and economic, people have developed positive attitudes towards learning the languages of other nations for the purpose of communication. In Europe, the educational policy has been modified to disseminate foreign language knowledge for the purpose of communicating one's self and enhancing intercultural communication among nations (Council of Europe, 2001). Specifically, one European initiative that was implemented in response to this linguistic move was the project of teaching German as a foreign language after English (Hufeisen and Neuner, 2004). The term “tertiary language" refers to those languages learned after the first foreign language.

The availability of digital media plays an important role in creating a more global world, as will be seen in this study. Digital media take various forms: YouTube, Instagram, Snapchat and many others. In terms of the English language, language educationalists have found digital media a helpful resource for teaching EFL inside and outside the classroom (see Aydin, 2001; Sundqvist, 2009; Turgut and Irgin, 2009; Kuppens, 2010). Mitra (2012) contributed significantly to the field of autonomous learning in out-of-class contexts. He examined the way in which Indian village children managed to learn computer skills and English via computers without receiving any formal instruction. His learning theory, known as the Self-Organised Learning Environment (SOLE), claims that learners can learn without help when learning resources are made available to them. In the Saudi Arabian context, few studies have examined the new linguistic pattern whereby Saudi youth and children are learning diverse foreign languages that do not have a strong presence in the country, such as Korean and Japanese, via digital media (Payne and Almansour, 2014; Alnofaie, 2016).

As this section demonstrates, the view of the world as a global village and the 
phenomenal spread of digital media have connected people together and have enriched intercultural communication among nations. Such global communication has encouraged people to learn non-world languages. The phenomenon of learning non-world languages draws our attention to the fact that some societies are moving towards plurilingualism, which means "to use languages for the purposes of communication and to take part in intercultural action" (Council of Europe, 2001: p. 168). Understanding this phenomenon will enrich the field of foreign language teaching and learning. It is the purpose of this study to determine the attitudes and motivation of young Saudis for learning foreign languages that do not have a strong presence in their country. This issue will be examined through the theory of L2 Motivational Self System theory (Dörnyei, 2005) in the following section.

\subsection{Theories of Language Learning Motivation}

One of the dominant theories of motivation is Dörnyei's (2005) theory of the L2 Motivational Self System theory, where L2 refers to a second or foreign language. This theory looks at the learner's psychology by identifying his attitudes towards learning a foreign language and his motivation, as manifested in his future self. Dörnyei's theory comes as a modified theory of Gardner's (1985) integrativeness theory (Dörnyei, 2005). According to Gardner, the two main components of motivation are integrativeness and instrumentality. Dörnyei (2005) views integrativeness as a broader concept that entails valuing the L2 community and culture and becoming a proficient L2 speaker. Dörnyei replaces the term integrativeness with the term L2 self-concept. This concept consists of three components: the ideal L2 self (i.e., what the learner wants to become), the ought-to-self (i.e., what others expect from the learner) and the learner's experience (i.e., the learner's efforts in learning the target language). Dörnyei applied his concept of the L2 Motivational Self System into a national study in Hungary (Dörnyei and Csizér, 2002). The study identified the motives of Hungarian students from different parts of the country in learning the foreign languages of English, French, German, Russian and Italian at two phases between the years 1993 and 1999. The study revealed that learners' choices of particular foreign languages were related to their geographical distance from the foreign countries and that there were gender differences in considering certain languages. Some other studies have applied Dörnyei's theory in order to validate this new concept. For instance, Taguchi et al. (2009) examined the concept of the ideal L2 self in three different contexts: Japan, China and Iran. The finding revealed that Dörnyei's concept of the L2 self is not context-specific and that integrativeness and instrumentality are related components. With regard to language motivation research in Saudi Arabia, a few studies have applied Dörnyei's (2005) concept of L2 Motivational Self System theory. For example, a study by Moskovsky et al. (2016) identified the components of EFL learning motivation (i.e. ideal L2 self, ought-to-self and L2 learner's experience) in relation to learners' intended ef- 
forts. Studies that examine the motivation of Saudis for learning other foreign languages are scarce (e.g., Alnofaie, 2016).

In order to contribute to the existing body of literature on foreign language learning motivation in Saudi Arabia, this study applies Dörnyei's concept of the L2 ideal self in the Saudi Higher Education (HE) context. The aim of this study is to provide a clear repertoire of the general motives of Saudi youth for learning different foreign languages in this age of globalisation and intercultural communication, via adapting Dörnyei's concept of the L2 ideal self. Since participants were learning English as an L2 and other foreign languages, the term L2+n will be used to refer to plurilingualism. Another purpose of this study is to highlight the need for a language teaching policy in the sector of Saudi HE, as informed by the findings of this study and other similar studies. The questions addressed by this study are:

1) What are the popular foreign languages learned by Saudi female undergraduates?

2) What language learning orientations underlie the participants' choice of certain foreign languages?

3) What are the learners' views of themselves as ideal L $2+n$ speakers?

In order to understand the emergence of foreign languages in Saudi Arabia, an overview of the history of foreign languages in the country is presented in the following section.

\subsection{Background of Foreign Languages in SA}

\section{The History of Foreign Languages in SA}

The total population of Saudi Arabia is 31.52 million. The number of Saudis is 21.1 millions, while the number of expatriates from different nationalities is 10.4 million (Rodolfo, 2016). Fifty percent of the population is below 25 years old ("Growing youth population in Saudi offers economic potential", 2013). Saudi Arabia is a monolingual country in which Arabic is the official language. There are communities of non-Arabs who work in the country and speak their mother tongues, as well as Saudis who are descended down from non-Arab origins and feel proud of retaining their mother tongues, such as Chinese, Indians and Caucasians. The country's economy is growing rapidly and plans are in place to use non-oil resources such as gas and mining, as well as a partnership between private and government sectors (Alfozan, 2017). At an international level, Saudi Arabia is the only Arab country that is a member of the G20 countries (countries of major economies) (Wahab, 2017). Also, the country has played a significantly international role in confronting terrorism, which is manifested in the establishment of the King Salman Center for Global Peace (Khan, 2017).

In terms of the history of teaching foreign languages in Saudi Arabia, Turkish was the first foreign language taught in the country before 1914 during the Ottoman reign. After the establishment of Saudi Arabia in 1932, one of the country's missions was to facilitate the education of its citizens in foreign countries, 
such as the USA and Britain. The school of scholarships introduced the English language to enable Saudis to pursue their education abroad. English was introduced into schools later and has continued as the only dominant foreign language in Saudi schools and universities until the present time (Mahboob \& Elyas, 2014). The educational policy of teaching English in Saudi schools emphasises the need for encouraging communication (see Elyas and Badawood (2017) for the translated English language teaching policy in Saudi schools). There is no educational policy for teaching English or foreign languages in general in Saudi's HE sector. It should be mentioned here that there are a few universities that provide BA degrees and short courses in foreign languages other than English, such as French, German and Turkish.

An ongoing debate in Saudi education and the Islamic world surrounds the influence of learning English on learners' identities. The concern is that learners might forget their Islamic and Saudi identities and thus language materials should be localised to reflect learners' culture and religion (Karmani, 2005). Islam has encouraged communication among nations. This communication is impossible to achieve without language.

O mankind! We have created you from a male and a female, and made you into nations and tribes, that you may know one another. Verily, the most honourable of you with Allah is that (believer) who has At-Taqwa [i.e. one of the Muttaqun (pious-see V.2:2). Verily, Allah is All-Knowing, Well-Acquainted. [Alhujurat: 13].

Saudi youth have reached a level at which they can learn English or any other foreign languages that are not common in their context outside their school walls. The availability of digital media has introduced Saudis to other cultures and languages. In 2016, the number of social media users in the country was 18 million (Ministry of Communication and Information Technology, 2016). Only a few studies have examined the way in which Saudi learners can communicate with other foreign cultures and engage in virtual communities via digital media (Payne \& Almansour, 2014; Alnofaie, 2016). The present paper is an extension of these studies. The following section introduces the methodology used in this study.

\section{Methodology}

The aim of this study was to identify the attitudes and motivations of young Saudi females towards learning different foreign languages that are uncommonly spoken in their own country. Data was collected by administering an online questionnaire adapted from Dörnyei \& Csizér (2002). The original questionnaire was designed to measure the attitudes and motivations of Hungarian school students towards learning other European languages at different phases in a longitudinal study. The present study collected the data at one phase since the author's intention was to identify the extent to which the phenomenon of learning uncommon foreign languages takes place. The target participants were under- 
graduate female students studying for their BA degrees in English language at a Saudi university. The participants were at different stages of their studies. The researcher had informal discussions with some of the undergraduates majoring in English as well as their teachers in order to identify some of the most popular languages being learned. The most popular languages that were initially identified were: Korean, Japanese and Turkish. Since the questionnaire used in this study was adapted from that of Dörnyei \& Csizér (2002) which was validated by other researchers from different contexts, it is considered both internally and externally valid. As a result of a pilot study by the researcher, a few minor changes were made. For example, the foreign languages in the original questionnaire by Dörnyei \& Csizér's (2002) (i.e., German, French, Russian, English and Italian) were replaced with the languages of interest to Saudi learners (i.e., English, Korean, Japanese and Turkish). Also, in the questionnaire design of this study, there was an option for these learners to add any other foreign languages that they were learning which were not listed. Questions 16, 18, 19 and 21 in the original study were merged into one question: I like following the media of (countries named). Participants in the research context, based on the researcher's experience, avoided participating in long surveys, so the researcher merged these similar items into one item. The total number of the questionnaire items was 33 items. Following the original questionnaire, the items included the 7 components: integrativeness, instrumentality, vitality of the L2 community, attitudes towards L2 speakers/community, cultural interest, linguistic self-confidence and milieu (see the Appendix for the full copy of this survey).

Data collection started in October 2016 and continued until December 2016. The questionnaire was sent to all 200 BA students majoring in English, but the number of respondents was 80 , between the ages of 18 and 25 . None of the participants had lived abroad for a period of more than 6 months. Descriptive analysis and correlation tests were employed for data analysis, using SPSS software. The questionnaire included open-ended questions which helped to obtain qualitative data. Although the study was a case study that took place at one Saudi university, generalisation was found to be possible. According to Flyvbjerg (2006), if the findings of case studies are compared, then generalisation is possible. The findings of this case study were aligned with those of Payne \& Almansour (2014) and Alnofaie (2016), who also explored the phenomenon of Saudi children learning uncommon foreign languages. These studies, along with the present study, highlight the linguistic move in the country among children and young people. This move requires educators to initiate a foreign language teaching policy that meets the needs and interests of learners in schools and HE sectors. The following section presents the results of this study.

\section{Results}

From Table 1 it can be seen that approximately $70.0 \%$ of the respondents spoke one foreign language, $26.3 \%$ spoke two languages and $3.8 \%$ spoke 3 languages. 
As can be observed in Table 2, 33.8\% of the respondents were learning foreign languages other than the four most popular foreign languages identified initially by the researcher: English, Korean, Japanese and Turkish.

Question 3 asked participants to list the learning resources they used to learn foreign languages. The participants mentioned a wide variety of digital media resources, such as Instagram, YouTube, learning websites and films. Learners mentioned the foreign languages they were learning and which were not listed in the questionnaire. Table 3 summarises these languages and shows the diversity of foreign languages learned by 56 participants.

Table 4 shows that that the mean value of learning English was higher among

Table 1. How many foreign languages are you speaking?

\begin{tabular}{cccccc}
\hline & & Frequency & Percent & Valid Percent & Cumulative Percent \\
\hline \multirow{3}{*}{ Valid } & 1 & 56 & 70.0 & 70.0 & 70.0 \\
& 2 & 21 & 26.3 & 26.3 & 96.3 \\
& 3 & 3 & 3.8 & 3.8 & 100.0 \\
& Total & 80 & 100.0 & 100.0 & \\
\hline
\end{tabular}

Table 2. Learning languages other than English, Korean, Japanese and Turkish.

\begin{tabular}{cccccc}
\hline & & Frequency & Percent & Valid Percent & Cumulative Percent \\
\hline \multirow{4}{*}{ Valid } & 0 & 2 & 2.5 & 2.5 & 2.5 \\
& Yes & 27 & 33.8 & 33.8 & 36.3 \\
& No & 51 & 63.8 & 63.8 & 100.0 \\
& Total & 80 & 100.0 & 100.0 & \\
\hline
\end{tabular}

Table 3. Other languages of interest to participants.

\begin{tabular}{ccc}
\hline Languages & Number of interested participants & Frequencies \\
\hline French & 24 & $30 \%$ \\
Japanese & 3 & $3.75 \%$ \\
Spanish & 5 & $6.25 \%$ \\
Italian & 1 & $1.25 \%$ \\
Turkish & 5 & $6.25 \%$ \\
Korean and Turkish & 2 & $2.5 \%$ \\
Russian & 1 & $1.25 \%$ \\
Persian & 2 & $2.5 \%$ \\
German & 1 & $1.25 \%$ \\
Urdu & 1 & $1.25 \%$ \\
Italian and French & 3 & $3.75 \%$ \\
Italian, French and Persian & 1 & $1.25 \%$ \\
Turkish and French & 1 & $1.25 \%$ \\
French and Japanese & 2 & $2.5 \%$ \\
French and German & 2 & $2.25 \%$ \\
\hline Fren and Persian & $25 \%$ \\
\hline
\end{tabular}


Table 4. Language learning preferences.

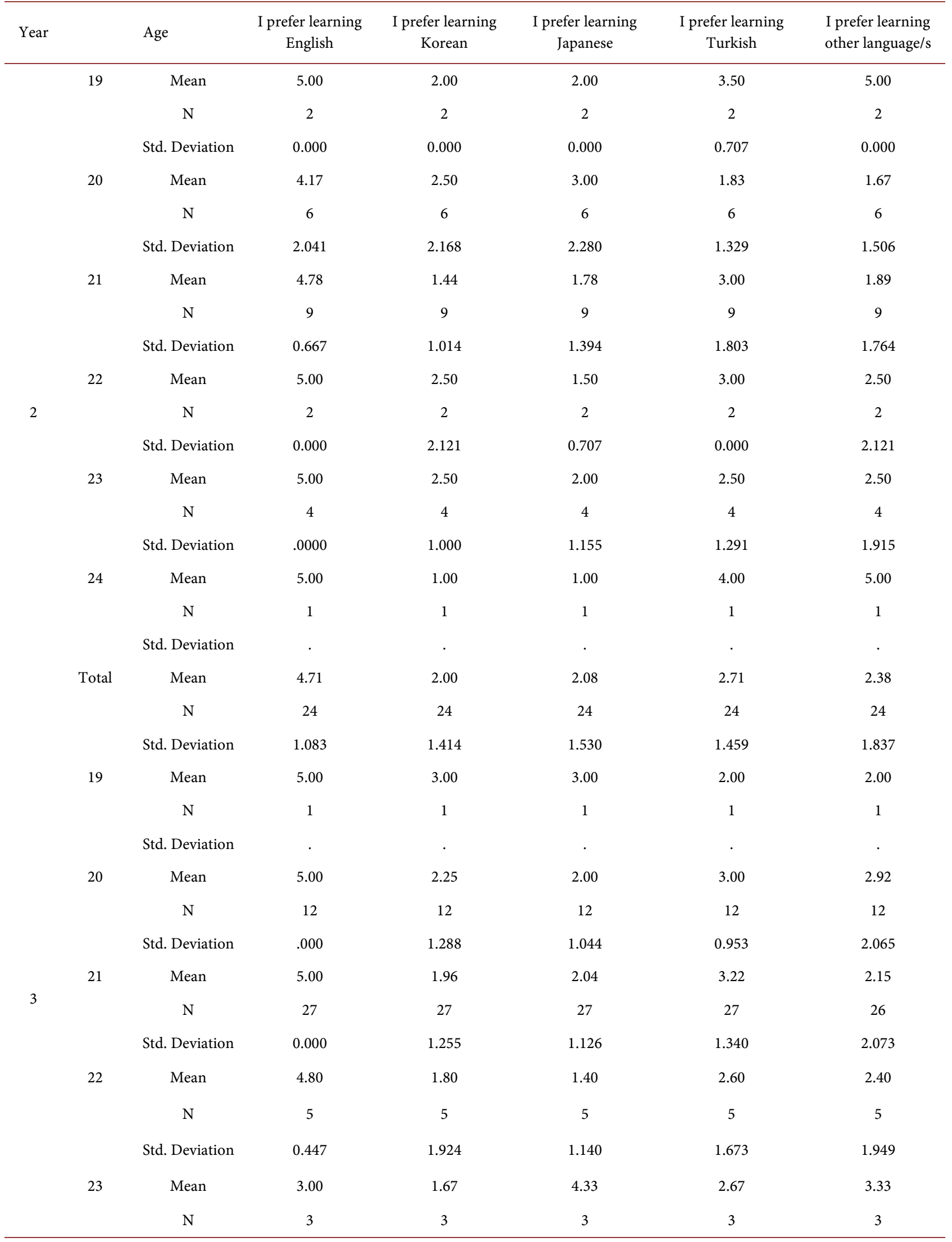




\section{Continued}

\begin{tabular}{|c|c|c|c|c|c|c|c|}
\hline & & Std. Deviation & 2.646 & 0.577 & 0.577 & 0.577 & 0.577 \\
\hline \multirow{3}{*}{\multicolumn{2}{|c|}{24}} & Mean & 5.00 & 2.00 & 4.00 & 3.00 & 3.00 \\
\hline & & $\mathrm{N}$ & 1 & 1 & 1 & 1 & 1 \\
\hline & & Std. Deviation & . & . & . & . & . \\
\hline \multirow{3}{*}{\multicolumn{2}{|c|}{25}} & Mean & 5.00 & 3.00 & 2.00 & 3.00 & 5.00 \\
\hline & & $\mathrm{N}$ & 1 & 1 & 1 & 1 & 1 \\
\hline & & Std. Deviation & . & . & . & . & . \\
\hline \multirow{3}{*}{\multicolumn{2}{|c|}{18}} & Mean & 5.00 & 2.00 & 4.00 & 2.00 & 4.00 \\
\hline & & $\mathrm{N}$ & 1 & 1 & 1 & 1 & 1 \\
\hline & & Std. Deviation & . & . & . & . & . \\
\hline \multirow{3}{*}{\multicolumn{2}{|c|}{ Total }} & Mean & 4.86 & 2.04 & 2.20 & 3.02 & 2.54 \\
\hline & & $\mathrm{N}$ & 51 & 51 & 51 & 51 & 50 \\
\hline & & Std. Deviation & 0.722 & 1.248 & 1.233 & 1.208 & 1.951 \\
\hline \multirow{3}{*}{\multicolumn{2}{|c|}{21}} & Mean & 5.00 & 2.00 & 4.00 & 2.00 & 3.00 \\
\hline & & $\mathrm{N}$ & 1 & 1 & 1 & 1 & 1 \\
\hline & & Std. Deviation & . & . & . & . & . \\
\hline \multirow{3}{*}{\multicolumn{2}{|c|}{22}} & Mean & 5.00 & 1.33 & 2.33 & 4.67 & 4.67 \\
\hline & & $\mathrm{N}$ & 3 & 3 & 3 & 3 & 3 \\
\hline & & Std. Deviation & 0.000 & 0.577 & 2.309 & 0.577 & 0.577 \\
\hline \multirow{3}{*}{\multicolumn{2}{|c|}{23}} & Mean & 5.00 & 1.00 & 1.00 & 3.00 & 0.00 \\
\hline & & $\mathrm{N}$ & 1 & 1 & 1 & 1 & 1 \\
\hline & & Std. Deviation & . & . & . & . & . \\
\hline \multirow{3}{*}{\multicolumn{2}{|c|}{ Total }} & Mean & 5.00 & 1.40 & 2.40 & 3.80 & 3.40 \\
\hline & & $\mathrm{N}$ & 5 & 5 & 5 & 5 & 5 \\
\hline & & Std. Deviation & 0.000 & 0.548 & 1.949 & 1.304 & 2.074 \\
\hline
\end{tabular}

the respondents of all age groups in the second, third and fourth years of study. This means that English maintains its popular status among Saudi youth.

Pearson's correlation test (Table 5) showed that the learning of English, Korean, Japanese, Turkish and any other languages had significant correlations with the preference of their respective languages during their second, third and fourth years. The importance of the status of English, Korean, Japanese, Turkish and any other language also had significant correlations with the preference of their respective languages during the second, third and fourth years. The respondents' best efforts to learn English, Korean, Japanese, Turkish and any other language had significant correlations with their preference to learn languages during their second, third and fourth years. Movement to their respective language speaking countries, leaning the language to help their career and wanting to become similar to people speaking different languages also had significant 
Table 5. Correlation between language learning preferences and survey variables.

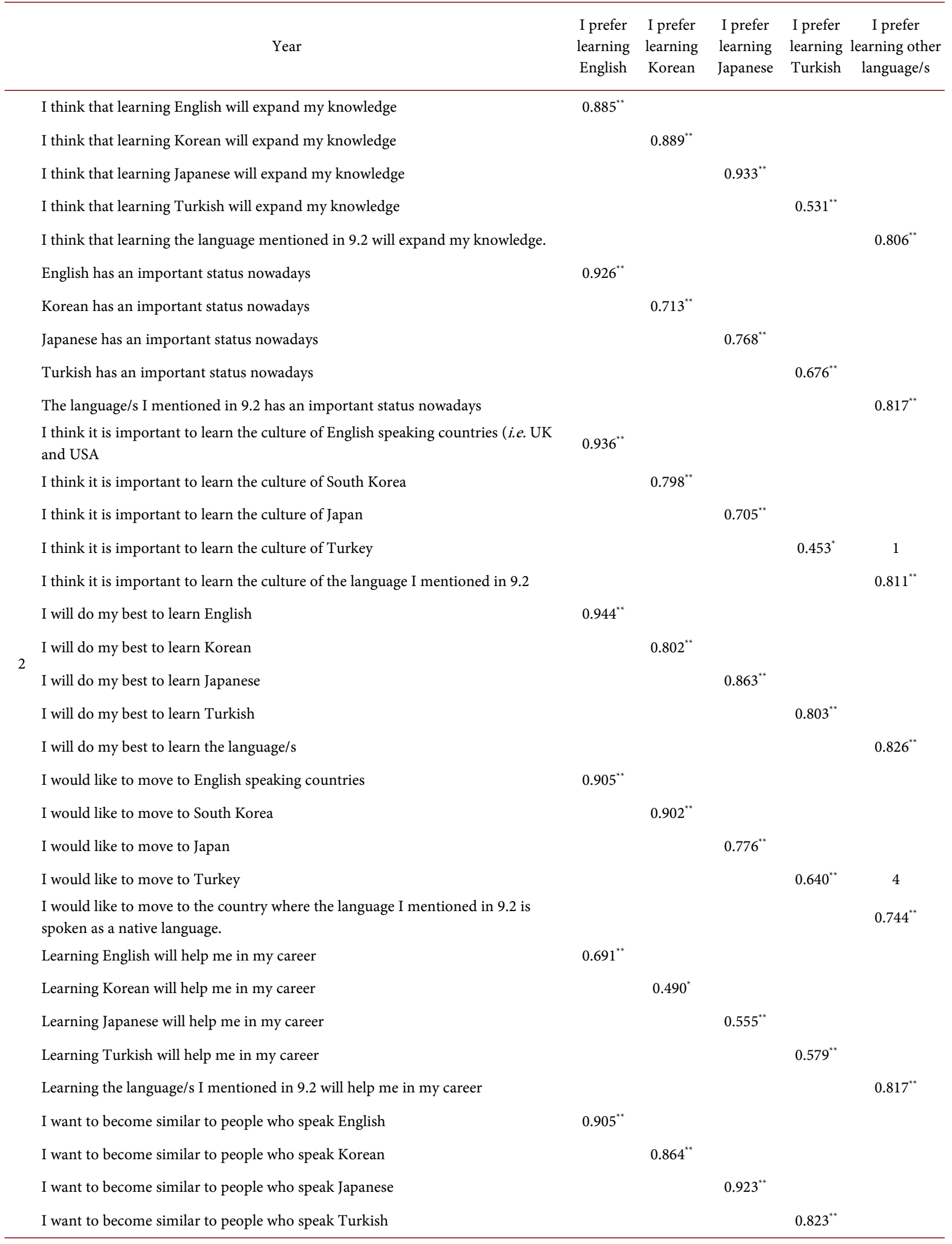




\section{Continued}

I want to become similar to people who speak the language/s I mentioned in 9.2

I like following the media of South Korea

$0.522^{* *}$

I like following the media of Japan

$0.580^{* *}$

I like following the media of Turkey

$0.697^{* *}$

I like following the media of the country I referred to in 9.2

$0.697^{* *}$

I think that learning English will expand my knowledge

0.185

I think that learning Korean will expand my knowledge

I think that learning Japanese will expand my knowledge

I think that learning Turkish will expand my knowledge

I think that learning the language mentioned in 9.2 will expand my knowledge.

English has an important status nowadays

$0.900^{* *}$

Korean has an important status nowadays

$-0.033$

Japanese has an important status nowadays

$0.525^{* *}$

Turkish has an important status nowadays

The language/s I mentioned in 9.2 has an important status nowadays

I think it is important to learn the culture of English speaking countries (i.e. UK and USA

I think it is important to learn the culture of South Korea

$0.752^{* *}$

I think it is important to learn the culture of Japan

$0.653^{* *}$

I think it is important to learn the culture of Turkey

I think it is important to learn the culture of the language I mentioned in 9.2

I will do my best to learn English

$-0.053$

I will do my best to learn Korean

$0.855^{* *}$

I will do my best to learn Japanese

I will do my best to learn Turkish

I will do my best to learn the language/s

I would like to move to English speaking countries

$-0.045$

I would like to move to South Korea

$0.700^{* *}$

I would like to move to Japan

$0.698^{* *}$

I would like to move to Turkey

I would like to move to the country where the language I mentioned in 9.2 is spoken as a native language.

Learning English will help me in my career

$-0.048$

Learning Korean will help me in my career

$0.530^{* *}$

Learning Japanese will help me in my career

$0.505^{* *}$

$0.760^{* *}$

Learning the language/s I mentioned in 9.2 will help me in my career

0.167

want to become similar to people who speak English

I want to become similar to people who speak Korean

$0.754^{* *}$ 


\section{Continued}

I want to become similar to people who speak Japanese

$0.566^{* *}$

I want to become similar to people who speak Turkish

$0.722^{* *} \quad 1$

I want to become similar to people who speak the language/s I mentioned in 9.2

$0.828^{* *}$

I would like to visit South Korea

$0.755^{*}$

I would Like to visit Japan

$0.695^{* *}$

I would like to visit Turkey

$0.660^{* *}$

I would like to visit the country/ies mentioned in 9.2

I find South Korea developed

$0.372^{* *}$

I find Japan developed

$0.479^{* *}$

I find Turkey developed

I find the country that I refer to its language in 9.2 developed

1

$0.828^{* *}$

English speaking countries like USA and UK have an important status in the world

$-0.116$

South Korea has an important status in the world

$0.326^{*}$

Japan has an important status in the world

$0.545^{* *}$

Turkey has an important status in the world

The country I referred to in 9.2 has an important status in the world

$0.825^{* *}$

I like following the media of English speaking countries like USA and UK

0.009

I like following the media of South Korea

$0.692^{* *}$

I like following the media of Japan

$0.578^{* *}$

I like following the media of Turkey

I like following the media of the country I referred to in 9.2

I think that learning English will expand my knowledge

I think that learning Korean will expand my knowledge

I think that learning Japanese will expand my knowledge

I think that learning Turkish will expand my knowledge

$0.908^{*}$

I think that learning the language mentioned in 9.2 will expand my knowledge.

English has an important status nowadays

Korean has an important status nowadays

0.49

Japanese has an important status nowadays

$0.903^{*}$

Turkish has an important status nowadays

0.772

The language/s I mentioned in 9.2 has an important status nowadays

0.838

I think it is important to learn the culture of English speaking countries (i.e. UK and USA

I think it is important to learn the culture of South Korea

I think it is important to learn the culture of Japan

I think it is important to learn the culture of Turkey

$.908^{*}$

I think it is important to learn the culture of the language I mentioned in 9.2 


\section{Continued}

I will do my best to learn English

I will do my best to learn Korean

I will do my best to learn Japanese

I will do my best to learn Turkish

I will do my best to learn the language/s

I would like to move to English speaking countries

I would like to move to South Korea

I would like to move to Japan

I would like to move to Turkey

I would like to move to the country where the language I mentioned in 9.2 is

spoken as a native language.

Learning English will help me in my career

Learning Korean will help me in my career

Learning Japanese will help me in my career

Learning Turkish will help me in my career

Learning the language/s I mentioned in 9.2 will help me in my career

I want to become similar to people who speak English

I want to become similar to people who speak Korean

I want to become similar to people who speak Japanese

I want to become similar to people who speak Turkish

I want to become similar to people who speak the language/s I mentioned in 9.2
0.721

$0.968^{* *}$

0.774

$1.000^{* *}$

0.721

$4 \quad 0.907^{*}$

0.572

0.859

0.48

0.5

$0.943^{*}$

$0.903^{*}$

0.48

$0.892^{*}$

$0.986^{*}$

Note: ${ }^{* *} p<0.01 ;{ }^{* *} p<0.05 ;{ }^{*} p<0.1$.

Table 6. Fears of identity loss.

\begin{tabular}{cccccc}
\hline & & Frequency & Percent & Valid Percent & Cumulative Percent \\
\hline \multirow{4}{*}{ Valid } & Strongly disagree & 64 & 80.0 & 80.0 & 80.0 \\
& Disagree & 12 & 15.0 & 15.0 & 95.0 \\
& Slightly agree & 3 & 3.8 & 3.8 & 98.8 \\
& Agree & 1 & 1.3 & 1.3 & 100.0 \\
& Total & 80 & 100.0 & 100.0 & \\
\hline
\end{tabular}

correlations with the preference for their respective languages during the second, third and fourth years. Expanding one's knowledge and the importance of learning the culture of foreign languages had significant correlations with the preference of their respective languages during second, third and fourth years.

From Table 6, we can observe that $80.0 \%$ of the respondents strongly disagreed that they might lose their Saudi identify if they learned foreign languages, and $15 \%$ disagreed with this statement. Only $3.8 \%$ slightly agreed that they might lose their identities and $1.3 \%$ agreed that identity loss might happen.

Regarding the influence of plurilingualism on participants' identity, the ma- 
jority of participants viewed foreign language learning as an additional credit that would strengthen their sense of belonging to their own country through communicating with others.

“... to develop my society and become more open to others." (Participant

23)

“... spread my culture which is unknown to many nations.” (Participant 28)

“... communicating with other nations and making friends from different nationties." (Participant 40)

Some participants viewed learning foreign languages as a tool for their empowerment:

"... to become an educated woman who can speak different languages."

(Participant 1)

"A woman can change society and I believe learning languages will help me to make a change in my society." (Participant 35 )

"The society will look at me as a smart and educated woman." (Participant 38)

Others admitted the importance of foreign languages for their future careers:

"Languages are important for travelling and employment." (Participant 33)

"I'm learning foreign languages to increase my self-confidence." (Participant 49)

"... communicating with other nations and increasing job opportunities." (Participant 41)

"I want to work as an interpreter." (Participant 64)

Some participants found that foreign languages meet their personal interests:

"Learning foreign languages is helpful for travelling and enhancing mental skills." (Participant 8 )

“... speaking with foreigners in my country." (Participant 15)

“... reading literature from different cultures and listening to their music and poetry." (Participant 47)

Continuing their education was another point that some participants raised as an advantage of learning languages:

“... to continue my studies abroad and communicate with other cultures." (Participant 2)

The participants provided more answers for the last question (Write any additional comments). Some of their answers were related to their reasons for learning foreign languages and reflected their awareness of the need for learning languages in the global era.

"Learning more than one foreign language is a requirement for this global era." (Participant 10) 
"People should realise the role of learning foreign languages in the spread of peace and humanity." (Participant 17)

Some responses expressed the participants' needs:

"Foreign languages should be taught earlier in schools." (Participant 21)

"We need classes for teaching other foreign languages." (Participant 55)

"Universities should offer degrees in diverse foreign languages." (Participant 77)

\section{Discussion}

The purpose of this paper was to understand the phenomenon of foreign language learning by Saudi female undergraduates. The study seeks to identify the foreign languages learned by this group of learners and to understand the participants' attitudes and motivations for learning these languages. One finding was that participants had positive attitudes towards learning foreign languages in addition to English $(\mathrm{L} 2+\mathrm{n})$. These languages vary from European languages, such as French and Italian, to East Asian languages, such as Japanese and Korean (see Tables 1-3). Participants were geographically distant from the foreign countries. Also, none of the participants had lived abroad for more than 6 months. Given this information about the participants, one might wonder why these participants then were interested in learning foreign languages. Globalisation via the availability of the internet and digital media has connected Saudis with other nations. As previously mentioned in the introduction, television channels and most social networks, such as Snapchat, YouTube, Facebook and others, are accessible. Digital media have enabled Saudis to connect easily with people from around the world and have influenced their language learning attitudes and motivations. This finding confirms those of other studies regarding the significant role of digital media in creating positive attitudes towards foreign language learning among Saudi learners from different age groups (Payne \& Almansour, 2014; Author). Also, it shows that globalisation has contributed to the spread of the English language as well as other non-world languages. Such a spread of diverse languages indicates the relationship between the two concepts of globalisation and plurilingualism, as the more people become connected nowadays, the more foreign languages will be learned.

Although the findings show that participants were interested in learning different foreign languages, English was considered to be the most important foreign language for the majority of these learners (see Table 4). This observation is in accordance with existing evidence regarding the global status of English (Crystal, 2003; Dörnyei \& Csizér, 2002). The participants in this study were all majoring in English and they were learning English because they valued the English language and its communities and for employment purposes (see Table 5). Concerning other foreign languages, participants identified themselves as Saudi citizens who value other nations and their cultures. Also, some partici- 
pants viewed themselves as successful speakers of foreign languages for career purposes (see Table 5). This point of self-identification is in tune with Dörnyei \& Csizér's (2002) interpretation of integrativeness, which entails valuing others and seeking proficiency for future career (i.e., instrumentality). Another finding related to participants' future selves was that the majority of them view themselves as Saudi nationals who can convey themselves and their culture to others via languages. This point indicates their pride in their Saudi identities. This finding seems to mitigate concerns raised about language learning and the possible loss of identity (Karmani, 2005).

The findings discussed above show the move towards plurilingualism among Saudi youth. They expand the narrow literature on foreign language learning in the Saudi context (Payne \& Almansour, 2014; Alnofaie, 2016). This study calls for the establishment of a foreign language policy in the Saudi HE sector, a policy that values the teaching and learning of various foreign languages. The main benefit of such a policy is to prepare young Saudis to become global citizens who can successfully adjust to this interconnected world without losing their national identities. Universities are encouraged to include foreign language programmes in order to meet learners' needs and interests. The introduction of foreign languages could be facilitated by activating the concept of SOLE (Mitra, 2012). Continuing education units in HE institutions can encourage out-of-class foreign language learning by providing students with language labs equipped with modern technologies, so students can learn languages of their choice during their free time in a collaborative environment. Such programmes will reinforce students' feelings of belonging to this interconnected globe.

\section{Conclusion and Implications for Future Research}

This is a survey-based study that explores the phenomenon of the spread of learning foreign languages among Saudi youth in a non-educational context. It draws on a repertoire of the way in which globalisation, via the availability of digital media, might affect the language learning of youths, relying on the L2 Motivational Self System theory. The participants consisted of 80 female undergraduate students who were studying for a BA degree in English. The study revealed that many of these students were learning other European and Asian languages in addition to English. The learners' motives emerged from their ideal $\mathrm{L} 2+\mathrm{n}$ selves, as they identified themselves as Saudi citizens who valued other nations and languages and as successful professionals. This linguistic move among Saudi youth has implications for the modification of the language education policy in the country to include other foreign languages in addition to English.

Since the topic of plurilingualism in Saudi Arabia is under-researched, this study raises the following important questions for future research: How would learning different foreign languages affect the identities of Saudi youth? What are the effects of incorporating plurilingualism into the policy of foreign lan- 
guage teaching in Saudi HE institutions? What are the gender differences in terms of the attitudes and motivations for learning foreign languages? It is hoped that this study might encourage language researchers from other Middle Eastern contexts to investigate the issue of learning rarely spoken foreign languages in their countries for comparative purposes.

\section{Acknowledgements}

I would like to express my deep gratitude to the participants who took part in this study for their cooperation and endless help.

\section{Funding}

This research did not receive any specific grant from funding agencies in the public, commercial, or not-for-profit sectors.

\section{References}

Alfozan, A. (2017). Saudi Economy to Maintain Growth in 2017 Despite Challenges. KPMG.

https://home.kpmg.com/sa/en/home/insights/2017/01/saudi-economy-to-maintain-gro wth-in-2017-despite-challenges.html

Alnofaie, H. (2016). The Attitudes and Motivation of Children towards Learning Rarely Spoken Foreign Languages: A Case Study from Saudi Arabia. International Journal of Bilingual Education and Bilingualism. https://doi.org/10.1080/13670050.2016.1184612

Aydin, S. (2001). The Use of the Internet in ESL Learning: Problems, Advantages and Disadvantages. Humanising Language Teaching, 1. http://www.hltmag.co.uk/jan07/sart02.htm

Council of Europe (2001). Common European Framework of Reference for Languages: Learning, Teaching and Assessment. Cambridge: Cambridge University Press.

Crystal, D. (2003). English as a Global Language (2nd ed.). Cambridge: CUP. https://doi.org/10.1017/CBO9780511486999

Dewey, J. (1993). The Problem of Truth. In D. Morris, \& I. Shapiro (Eds.), John Dewey: The Political Writing (pp. 10-19). Indianapolis: Hackett.

Dörnyei, Z. (2005). The Psychology of the Language Learner: Individual Differences in Second Language Acquisition. Mahwah, NJ: Lawrence Erlbaum.

Dörnyei, Z., \& Csizer, K. (2002). Motivational Dynamics in Second Language Acquisition: Results of a Longitudinal Nationwide Survey. Applied Linguistics, 23, 421-462. https://doi.org/10.1093/applin/23.4.421

Elyas, T., \& Badawood, O. (2017). English Language Educational Policy in Saudi Arabia Post 21st Century: Enacted Curriculum, Identity, and Modernisation: A Critical Discourse Analysis Approach. FIRE: Forum for International Research in Education, 3, 70-81. http://preserve.lehigh.edu/fire/vol3/iss3/3/

Flyvbjerg, B. (2006). Five Misunderstandings about Case-Study Research. Qualitative Inquiry, 12, 219-245. https://doi.org/10.1177/1077800405284363

Gardner, R. C. (1985). Social Psychology and Second Language Learning: The Role of Attitudes and Motivation. London: Edward Arnold.

Giddens, A. (2001). The Global Third Way Debate. Cambridge: Polity.

Growing Youth Population in Saudi Offers Economic Potential (2013). Arab News. 
http://www.arabnews.com/news/462135

Hufeisen, B., \& Neuner, G. (2004). The Plurilingualism Project: Tertiary Language Learning: German after English. Strasbourg: Council of Europe Publishing.

Karmani, S. (2005). TESOL in a Time of Terror: Towards an Islamic Perspective on Applied Linguistics. Tesol Quarterly, 39, 738-744. https://doi.org/10.2307/3588534

Khan, G. (2017). Saudi Arabia, Malaysia to Establish "King Salman Center for Global Peace”. Arab News. http://www.arabnews.com/node/1061896/saudi-arabia

Kubota, R. (2002). The Impact of Globalisation on Language Teaching in Japan. In D. Block, \& D. Cameron (Eds.), Globalization and Language Teaching (pp. 13-28). London: Routledge.

Kuppens, A. H. (2010). Incidental Foreign Language Acquisition from Media Exposure. Learning, Media and Technology, 35, 65-85. https://doi.org/10.1080/17439880903561876

Mahboob, A., \& Elyas, T. (2014). English in the Kingdom of Saudi Arabia. World Englishes, 33, 128-142. https://doi.org/10.1111/weng.12073

Ministry of Communication and Information Technology (2016). Facebook and Twitter Top in Number of Users, Over 18 Million Users of Social Media Programs and Applications in Saudi Arabia. http://www.mcit.gov.sa/En/MediaCenter/Pages/News/News-22032016_982.aspx

Mitra, S. (2012). Beyond the Hole in the Wall: Discover the Power of Self-Organised Learning. TED Books. https://doi.org/10.1111/j.1469-5812.2005.00139.x

Moskovsky, C., Assulaimani, T. Racheva, S., \& Harkins, J. (2016). The L2 Motivational Self System and L2 Achievement: A Study of Saudi EFL Learners. The Modern Language Journal, 100, 641-654. https://doi.org/10.1111/modl.12340

Papastephanou, M. (2005). Globalisation, Globalism and Cosmopolitanism as an Educational Ideal. Educational Philosophy and Theory, 37, 533-551.

https://doi.org/10.1111/j.1469-5812.2005.00139.x

Parjanadze, N. (2009). Globalisation Theories and Their Effect on Globalisation. Scientific Journal of International Black Sea University, 3, 77-88.

http://econpapers.repec.org/article/ibljournl/v_3a3_3ay_3a2009_3ai_3a2_3ap_3a77-88. htm

Payne, M., \& Almansour, M. (2014). Foreign Language Planning in Saudi Arabia: Beyond English. Current Issues in Language Planning, 15, 327-342.

https://doi.org/10.1080/14664208.2014.915461

Rodolfo, C. E. (2016). KSA Population: 21.1m Saudis, 10.4m Expats. Arab News. http://www.arabnews.com/featured/news/875131

Sundqvist, P. (2009). Extramural English Matters: Out-of-School English and Its Impact on Swedish Ninth Graders' Oral Proficiency and Vocabulary. PhD Diss., Karlstad University.

Taguchi, T., Magid, M., \& Papi, M. (2009). The L2 Motivational Self System among Japanese, Chinese and Iranian Learners of English: A Comparative Study. In Z. Dörnyei, \& E. Ushioda (Eds.), Motivation, Language Identity and the L2 Self (pp. 66-97). Bristol: Multilingual Matters.

Turgut, Y., \& İrgin, P. (2009). Young Learners' Language Learning via Computer Games. Procedia-Social and Behavioral Sciences, 1, 760-764.

Wahab, S. (2017). Saudi Arabia to Host 2020 G20 Summit. Arab News. http://www.arabnews.com/node/1126286/world 


\section{Appendix}

Survey: Attitudes towards and motivation for learning foreign languages Adapted from Dörnyei and Csizér (2002)

We would like you to help us to answer the following questions concerning foreign language learning. There are no right or wrong answers. We are interested in your personal opinion. You don't need to mention your name. Thank you very much for your help.

Participant age:

Year of study:

1. Are you interested in learning foreign languages?
a) Very much interested
b) quiet a lot
c) so-so
d) not really
e) not at all

\section{How many foreign languages are you speaking?}

3.1. Have you learned foreign languages outside the classroom?
a) Yes
b) No

3.2. If you answered yes, what are these languages.

4. What are the learning resources you used to learn these languages?

5. When did you start learning these languages?
a) before 12
b) between 12 and 18
c) after 18

6.1. Have you stayed in a foreign country for a period of more than 6 months?
a) Yes
b) no

6.2. If yes, mention this country.

7. What are the foreign languages that you are planning to learn in the future?

8. How would you think that learning foreign languages might affect your life as a Saudi woman?

9.1. The following foreign languages are becoming popular among Saudi 
youth: English, Korean, Japanese and Turkish. Are you learning languages that are not mentioned here.
a) Yes
b) No

\subsection{If yes what are these languages?}

10. Choose ONE answer for each of the following questions. Use these scales:

$$
\begin{array}{ll}
1=\text { strongly disagree } & 2=\text { disagree } \quad 3=\text { slightly agree } \\
4=\text { agree } & 5=\text { strongly agree }
\end{array}
$$

10.1. I prefer learning English
1.
2.
3.
4.
5.

10.2. I prefer learning Korean
1.
2.
3.
4
5

10.3. I prefer learning Japanese
1.
2.
3.
4.
5.

10.4. I prefer learning Turkish
1.
2.
3.
4.
5.

10.5. I prefer learning the language/s I mentioned in Questions 9.2
1.
2.
3.
4.
5.

11.1. I think that learning English will expand my knowledge
1.
2.
3.
4.
5.

11.2. I think that learning Korean will expand my knowledge
1.
2.
3.
4.
5.

11.3. I think that learning Japanese will expand my knowledge
1.
2.
3.
4.
5.

11.4. I think that learning Turkish will expand my knowledge
1.
2.
3.
4.
5.

11.5. I think that learning the language mentioned in 9.2 will expand my knowledge.
1.
2.
3.
4 .
5.

12.1. English has an important status nowadays
1.
2.
3.
4.
5.

12.2. Korean has an important status nowadays
1.
2.
3.
4.
5.

12.3. Japanese has an important status nowadays
1.
2.
3.
4.
5.

12.4. Turkish has an important status nowadays
1.
2.
3.
4.
5.

12.5. The language/s I mentioned in 9.2 has an important status nowadays
1.
2.
3.
4.
5. 
13.1. I think it is important to learn the culture of English speaking countries (i.e. UK and USA)

1. $2 . \quad 3 . \quad 4 . \quad 5$.

13.2. I think it is important to learn the culture of South Korea

1.2 . 2.04.

13.3. I think it is important to learn the culture of Japan

1. $2 . \quad 3 . \quad 4 . \quad 5$.

13.4. I think it is important to learn the culture of Turkey

$\begin{array}{lllll}1 . & 2 . & 3 . & \end{array}$.

13.5. I think it is important to learn the culture of the language I mentioned in 9.2
1.
2.
3.
4 .
5.

14.1. I will do my best to learn English
1.
2.
3.
4 .
5.

14.2. I will do my best to learn Korean
1.
2.
3.
4 .
5.

14.3. I will do my best to learn Japanese
1.
2.
3.
4.
5.

14.4. I will do my best to learn Turkish
1.
2.
3.
4.
5.

14.5. I will do my best to learn the language/s I mentioned in 9.2
1.
2.
3.
4.
5.

15.1. I would like to move to English speaking countries
1.
2.
3.
4.
5.

15.2. I would like to move to South Korea
1.
2.
3.
4.
5.

15.3. I would like to move to Japan
1.
2.
3.
4.
5.

15.4. I would like to move to Turkey
1.
2.
3.
4.
5.

15.5. I would like to move to the country where the language I mentioned in 9.2 is spoken as a native language.
1.
2.
3.
4 .
5.

16.1. Learning English will help me in my career
1.
2.
3.
4.

16.2. Learning Korean will help me in my career
1.
2.
3.
4.
5.

16.3. Learning Japanese will help me in my career
1.
2.
3.
4.
5.

16.4. Learning Turkish will help me in my career
1.
2.
3.
4.
5. 
16.5. Learning the language/s I mentioned in 9.2 will help me in my career
1.
2.
3.
4.
5.

17.1. I want to become similar to people who speak English
1.
2.
3.
5.

17.2. I want to become similar to people who speak Korean
1.
2.
3.
4.
5.

17.3. I want to become similar to people who speak Japanese

1. 2.04 . $\quad 3$.

17.4. I want to become similar to people who speak Turkish

1.

2.

3.

4.

5.

17.5. I want to become similar to people who speak the language/s I mentioned in 9.2
1.
2.
3.
4.
5.

18.1. My parent(s) speak English
a) Yes
b) No

18.2. My parent(s) speak South Korean
a) Yes
b) No

18.3. My parent(s) speak Japanese
a) Yes
b) No

18.4. My parent(s) speak Turkish
a) Yes
b) No

18.5. My parent(s) speak the language that I referred to in 9.2
a) Yes b
) No

19.1. I would like to visit English speaking countries (USA, UK).
1.
2.
3.
4.
5.

( 1 = strongly disagree $5=$ strongly agree $)$

19.2. I would like to visit South Korea
1.
2.
3.
4.
5.

19.3. I would Like to visit Japan

1. $2 . \quad 3 . \quad 4$.

19.4. I would like to visit Turkey
1.
2.
4.
5.

19.5. I would like to visit the country/ies mentioned in 9.2
1.
2.
4.
5.

20.1. I find English speaking countries like USA and UK developed countries.
1.
2.
3.
4.
5.

20.2. I find South Korea developed

1. $2 . \quad 3 . \quad 4$.

20.3. I find Japan developed
2.
3.
5. 
20.4. I find Turkey developed

1. $2.03 . \quad 4 . \quad 5$.

20.5. I find the country that I refer to its language in 9.2 developed
1.
2.
3.
4.
5.

21.1. English speaking countries like USA and UK have an important status in the world
1.
2.
3.
5.

21.2. South Korea has an important status in the world

$\begin{array}{lllll}1 . & 2 . & 3 . & 4 . & 5 .\end{array}$

21.3. Japan has an important status in the world
1.
2.
3.
5.

21.4. Turkey has an important status in the world
1.
2.
3.
4.
5

21.5. The country I referred to in 9.2 has an important status in the world
1.
2.
4.
5.

22.1. I like people from English speaking countries like USA and UK
1.
2.
3.
4.

22.2. I like people from South Korea
1.
2.
3.
4.
5.

22.3. I like people from Japan
1.
2.
3.
4
5

22.4. I like people from Turkey
1.
2.
3.
4.
5.

22.5. I like people from the country I referred to in 9.2
1.
2.
3.
4.
5.

23.1. I like following the media of English speaking countries like USA and UK 1. 2

3. 5 23.2. I like following the media of South Korea
1.
2.
3.
4.
5.

23.3. I like following the media of Japan
1.
2.
3.
4.
5.

23.4. I like following the media of Turkey
1.
2.
3.
4.
5.

23.5. I like following the media of the country I referred to in 9.2
1.
2.
3.
4.
5.

24.1. How often do you meet people from English speaking countries like USA and UK?

$\begin{array}{lllll}1 \text {. very often } & 2 \text {. quite a lot } & 3 \text {. sometimes } & 4 \text {. rarely } & 5 \text {. never }\end{array}$

24.2. How often do you meet people from South Korea

$\begin{array}{lllll}1 \text {. very often } & 2 \text {. quite a lot } & 3 \text {. sometimes } & 4 \text {. rarely } & 5 \text {. never }\end{array}$ 
24.3. How often do you meet people from Japan

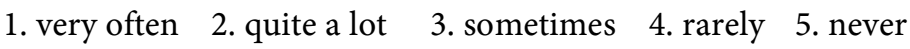

24.4. How often do you meet people from Turkey

1. very often 2. quite a lot 3 . sometimes 4 . rarely 5 . never

24.5. How often do you meet people from the country I referred to in 9.2

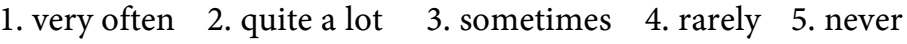

25. I can learn languages well

1. $2 . \quad 3 . \quad 4 . \quad 5$.

( 1 = strongly disagree $5=$ strongly agree $)$

26. I feel anxious about speaking the foreign language

1. 2.4 . $\quad 3$.

( 1 = strongly disagree 5 = strongly agree $)$

27. My friends believe in the importance of learning foreign languages

1. $2 . \quad 3 . \quad 4$.

( 1 = strongly disagree $5=$ strongly agree $)$

28. Teaching foreign languages in schools is important

1. 2.4 . $\quad 3$.

$(1=$ strongly disagree $5=$ strongly agree $)$

29.My parents believe in the importance of teaching foreign languages in school
1.
2.
3.
4.
5.

( 1 = strongly disagree $5=$ strongly agree $)$

30. My parents encourage me to learn foreign languages
1.
2.
3.
4.
5.

( 1 = strongly disagree 5 = strongly agree)

31. I might lose my Saudi identity if I learn foreign languages
2.
3.
4.
5.

( 1 = strongly disagree 5 = strongly agree)

32. Learning a foreign language is a difficult task.

1. 2. 3. 4. 5. ( $1=$ strongly disagree $5=$ strongly agree $)$

33. Please write any additional comments in the box below. 